\title{
OPEN Author Correction: Interplay of fibroblasts with anaplastic tumor cells promotes follicular thyroid cancer progression
}

\author{
Laura Fozzatti, Vanina Alejandra Alamino, Sunmi Park, Lucila Giusiano, Ximena Volpini, \\ Li Zhao, Cinthia Carolina Stempin, Ana Carolina Donadio, Sheue-yann Cheng \& \\ Claudia Gabriela Pellizas
}

Correction to: Scientific Reports https://doi.org/10.1038/s41598-019-44361-6, published online 29 May 2019

The Acknowledgements section in this Article is incomplete.

"We thank M. P. Abadie and M. P. Crespo for their excellent technical assistance. We also thank Woo Kyung Lee of National Cancer Institute for providing the media from normal thyroid cells for the analysis of platelet-derived growth factor. The present research was supported by research grants from the Intramural Research Program at the Center for Cancer Research, (CCR, NCI, NIH), Consejo Nacional de Investigaciones Científicas y Técnicas (CONICET, PIP 112-20150100810), Agencia Nacional de Promoción Científica y Técnica (y PICT 2015-0340), Secretaría de Ciencia y Técnica (SeCyT, Universidad Nacional de Córdoba) and L.F. is grateful to CONICET to fund international activities."

should read:

"We thank M. P. Abadie and M. P. Crespo for their excellent technical assistance. We also thank Woo Kyung Lee of National Cancer Institute for providing the media from normal thyroid cells for the analysis of platelet-derived growth factor. The present research was supported by research grants from the Intramural Research Program at the Center for Cancer Research, (CCR, NCI, NIH), Consejo Nacional de Investigaciones Científicas y Técnicas (CONICET, PIP 112-20150100810), Agencia Nacional de Promoción Científica y Técnica (PICT 2015-0340), Secretaría de Ciencia y Técnica (SeCyT, Universidad Nacional de Córdoba) and Fundación Sales. Also, L.F. is grateful to CONICET to fund international activities"

(i) Open Access This article is licensed under a Creative Commons Attribution 4.0 International License, which permits use, sharing, adaptation, distribution and reproduction in any medium or format, as long as you give appropriate credit to the original author(s) and the source, provide a link to the Creative Commons license, and indicate if changes were made. The images or other third party material in this article are included in the article's Creative Commons license, unless indicated otherwise in a credit line to the material. If material is not included in the article's Creative Commons license and your intended use is not permitted by statutory regulation or exceeds the permitted use, you will need to obtain permission directly from the copyright holder. To view a copy of this license, visit http://creativecommons.org/licenses/by/4.0/.

(C) The Author(s) 2019 